\title{
Heritage Stones and Geoheritage
}

\author{
Dolores Pereira ${ }^{1}$. Víctor Cárdenes Van den Eynde ${ }^{2}$
}

Published online: 22 February 2019

(C) The European Association for Conservation of the Geological Heritage 2019

In 2016, at the International Geological Congress that took place in Cape Town, South Africa, the IUGS Council ratified the creation of a new IUGS Commission: the International Commission for Geoheritage. In this commission, both heritage sites and heritage stones working groups will collaborate to disseminate the importance of Geoheritage for the general public and for the scientific community. Since then, a great effort has been made to join both subjects in meetings and in publications. Heritage Stones and Geoheritage is a special issue dedicated to spread news on some natural stones with implications on heritage around the world, and also on mines and quarries that are part of our Geoheritage and industrial heritage. It is a contribution of the IUGS Heritage Stones Subcommission. Our aim is to make as public as possible the importance of natural stones in the architectonic heritage in particular and in the geoheritage context in general. In fact, one of the papers deals with the importance of outreach through museums (Pereira and Pérez-Castro, 2017), where part of the sculptures, or the full sculptures, is made on stone. Those stones are related many times to the cultural heritage of societies. It is therefore important to emphasize the need to preserve the historical quarries that once upon a time where the source for all these stones linked to the culture and local society, and nowadays, because the change in transportation, infrastructures, or even globalization related to imports and exports of exotic dimension stones, are not quarried anymore. But because the specific technical and aesthetical characteristics of the heritage stones, these historical quarries should be preserved and used, sometimes with restrictions, in case of restoration of monuments and historical buildings to avoid

Dolores Pereira

mdp@usal.es

1 Heritage Stone Subcommission (IUGS), Institute for Social Studies on Science and Technology, Universidad de Salamanca, 37008 Salamanca, Spain

2 Departamento de Geología, Universidad de Oviedo, C/ Jesús Arias de Velasco s/n, 33005 Oviedo, Spain the disastrous actions that have been observed in restoration even in World Heritage Cities.

This special issue is made up of 12 papers that have been sourced from contributions to sessions on Heritage Stones that were held as part of the European Geosciences Union General Assembly in 2016 and 2017, supplemented with contributions from other international meetings, like the International Geological Congress that took place in Cape Town in 2016.

The selection of papers includes the study by Cardenes et al. (2017) presenting the history of the slates industry in Spain and its relationship with Geoheritage and industrial heritage. Careddu and Grillo (2017) explain how an ancient resource, such as basalts in Sardinia, is still in use and should be preserved. Costa et al. (2017) describe a mining site, the Traversella site, as a geosite. It is an iron deposit that was exploited from Medieval age up to the middle of the twentieth century, when most mining activities in Europe were reduced or ceased because of the drop in price of the metallic resources. Now, the site is appreciated for educational and touristic reasons. Gambino et al. (2017) offer a mobile application to follow the Geology of Torino streets through the natural stones used in the construction of the city and its buildings. Kullberg and Prego (2017) describe the fascinating Arrábida breccia. This stone is part of many historical buildings in Portugal that are considered world architectonic heritage by the UNESCO. This paper is accompanied by some entertaining videos, with aerial views of those buildings, but also the extracting sites of the stone. Navarro et al. (2017) describe the importance of a white marble extracted in Andalucia since ancient times: White Macael. This marble is part of many historical buildings in Spain and has been presented as a candidate for recognition as Global Heritage Stone Resource (Cooper et al. 2013). Pereira and Pérez-Castro (2017) show how art museums can be used as geoscience outreach if the stones used in sculptures, pedestals for sculptures, and the ornaments of the buildings are explained and characterized properly, and not only as "stones" or "marbles", when most of the times are not. Semeniuk and Brocx (2017) 
lead us through some building stones to convince the reader on their importance in Geoheritage. Here, the authors explain how some natural stones have been recognized by heritage features such as cultural, historical, archeological, and architectural. Now, natural stones can be identified also by their importance to geoheritage. Zenaide Silva, Brazilian by birth, but living and working in Lisbon for a great part of her life, makes a connection between both countries through the limestone from Lioz, extracted in Portugal, but also used in the building of colonial Brazil (Silva 2017b). Carlos Silva (2017a) describes how stones serve as decorative elements in the streets of Lisbon, helping also to explain geodiversity. Emanuel Costa (2017) describes the potential of an abandoned quarry to enhance local cultural heritage. FreireLista (2017) describes the Barrio de las Letras, in Madrid, Spain, as an example of the importance of natural stones in the preservation of historical city centers.

This volume is an additional contribution to studies on the currently important issue of natural stone use in architectural heritage and complements other special issues published by the Geological Society of London as Geological Society Special Publications (e.g., Pereira et al. 2015a), a special issue on Heritage Stones published in Episodes (Pereira et al. 2015b) and another one published by Geoscience Canada (Pereira and Pratt, 2016). It is our hope to keep contributing with future issues on the same subject.

Acknowledgements The Guest Editors of the issue greatly appreciate the work of the authors and reviewers as well as the IUGS that supports the continuous work of the HSS and the IGCP-637 that has partially funded the participation of some of the contributors to the Heritage Stones meetings related above.

\section{References}

Cardenes V, Ponce de León M, Rodríguez XA, Rubio-Ordoñez A (2017) Roofing slate industry in Spain: history, geology, and geoheritage. Geoheritage this volume

Careddu N, Grillo S (2017) Sardinian basalt. An ancient georesource still en vougue. Geoheritage this volume

Cooper BJ, Marker BR, Pereira D, Schouenborg B (2013) Establishment of the "Heritage Stone Task Group" (HSTG). Episodes 36-1:8-10

Costa E (2017) Touristic fruition of the disused quarry of Busca Onyx: problematics and strategies. Geoheritage this volume

Costa E, Dino GA, Benna P, Rossetti P (2017) The Traversella mining site as Piemonte geosite. Geoheritage this volume

Freire-Lista D (2017) Historical city centres and traditional building stones as heritage: Barrio de las Letras, Madrid (Spain). Geoheritage this volume

Gambino F, Borghi A, d'Atri A, Gallo LM, Ghiraldi L, Giardino M, Martire L, Palomba M, Perotti L, Macadam J (2017) TOURinSTONES: a free mobile application for promoting geological heritage in the city of Torino (NW Italy). Geoheritage this volume

Kullberg JC, Prego A (2017) The historical importance and architectonic relevance of the "extinct" Arrábida Breccia. Geoheritage this volume

Navarro R, Pereira D, Cruz AS, Carrillo G (2017) The significance of "white macael" marble since ancient times: characteristics of a candidate as global heritage stone resource. Geoheritage this volume

Pereira D, Pérez-Castro P (2017) Art museums: a good context for outreach activities on natural stones and heritage. Geoheritage this volume

Pereira D, Pratt BM (eds) (2016) Heritage stones of the world: introduction to the new series. Geosci Can 43:3

Pereira D, Marker B, Kramar S, Cooper B, Schouenborg B (Eds) (2015a) Global heritage stone: towards international recognition of building and ornamental stones, geological society special publications 407

Pereira D, Kramar S, Cooper B (eds) (2015b) Heritage stones: an update. Episodes 38-2

Semeniuk V, Brocx M (2017) Building stones can be of geoheritage significance. Geoheritage this volume

Silva C (2017a) Urban geodiversity and decorative arts: the curious case of the "rudist tiles" of Lisbon (Portugal). Geoheritage this volume

Silva Z (2017b) Lioz - a royal stone in portugal and a monumental stone in colonial Brazil. Geoheritage this volume 